\title{
MONITOROWANIE ZIELONEJ GOSPODARKI W UJĘCIU ORGANIZACJI MIĘDZYNARODOWYCH
}

\begin{abstract}
Streszczenie
Pojęcie zielonej gospodarki, które ściśle jest powiązane z koncepcją zrównoważonego rozwoju, rozwinęło się stosunkowo niedawno, kiedy to w 2008 roku Program Środowiskowy Narodów Zjednoczonych (UNEP) wezwał do podjęcia Inicjatywy Zielonej Gospodarki, znanej jako Globalny Zielony Nowy Lad, dostrzegając możliwości i szanse na wyjście z ogólnoświatowego kryzysu gospodarczego dzięki rozwojowi sektorów zielonej gospodarki. Tematykę zielonej gospodarki podjęły także i inne organizacje międzynarodowe, m.in. Organizacja Współpracy Gospodarczej i Rozwoju (OECD) oraz Europejska Agencja Środowiska (EEA). Wraz z rozwojem tej inicjatywy pojawiła się konieczność wykształcenia metod monitorowania i oceny stopnia jej zazielenienia. Rzetelne, właściwie dobrane i aktualne dane o stanie zazielenienia gospodarki sa istotnym elementem wdrażania polityk ochrony środowiska, stosowania instrumentów gospodarczych (np.: podatków, dotacji) czy też działań pobudzających innowacje ekologiczne i inwestycje w zielone technologie, oraz monitorowania skuteczności tych działań. Dostarczają one cennych informacji na temat konkretnych wyzwań stojących przed zieloną gospodarką, a umieszczone w szerszym kontekście umożliwiają śledzenie zmian zachodzących w: gospodarce, środowisku i społeczeństwie. Uwzględniając dotychczasowe podejścia ugrupowań międzynarodowych oraz doświadczenia krajów w monitorowaniu zielonej gospodarki, w Polsce także podjęto przygotowania do opracowania metodologii jej pomiaru.

Celem artykułu jest przedstawienie ujęcia zielonej gospodarki oraz wskaźników jej pomiaru będących dorobkiem trzech organizacji międzynarodowych, a mianowicie: UNEP, OECD i EEA.
\end{abstract}

Słowa kluczowe: zielona gospodarka, elementy zielonej gospodarki, wskaźniki monitorowania

\section{MONITORING OF GREEN ECONOMY: INTERNATIONAL EXPERIENCE}

\section{Summary}

The notion of the green economy, which is closely related to the concept of sustainable development, has evolved relatively recently, when in 2008 the United Nations Environment Programme (UNEP) called for a Green Economy Initiative, known as the Global Green New Deal, recognizing the possibilities and opportunities for overcoming the global economic crisis through the development of green economy sectors. The topic of the green economy has also been undertaken by other interna-tional organizations, such as, e.g., the Organization for Economic Cooperation and Development (OECD) and the European Environment Agency (EEA). The development of green economy initiatives has brought a need to create methods for the monitoring and assessment of the degree of greening of particular economies. Reliable, properly selected and current data on the greening of an economy are extremely helpful in the implementation of environmental policies, the use of economic instruments (such as taxes or subsidies), or activities that stimulate eco-innovations and investments in green technologies, as well as in monitoring of the effectiveness of those

1 dr Dorota Wyszkowska - Urząd Statystyczny w Białymstoku, Uniwersytet w Białymstoku; e-mail: dwyszkowska@op.pl; mgr Anna Rogalewska - Urząd Statystyczny w Białymstoku; e-mail: a.rogalewska@ stat.gov.pl. 
actions. They provide valuable information on the specific challenges facing the green economy and, placed in a broader context, enable to track changes in the economy, environment and society. Taking into consideration the current approaches of international groups and the experience of countries in monitoring the green economy, also in Poland preparations have been undertaken to develop a methodology of its measurement.

The purpose of this article is to present the concepts and indicators of the green economy used by three international organizations: UNEP, OECD and EEA.

Key words: green economy, elements of green economy, indicators of monitoring

\section{Wstęp}

$\mathrm{Na}$ forum międzynarodowym, jak również w literaturze funkcjonują dwa pojęcia i definicje związane z zieloną gospodarką, tj.:

- green economy - termin, który można odnaleźć w opracowaniach Programu Środowiskowego Narodów Zjednoczonych (United Nations Environment Programme - UNEP) lub Europejskiej Agencji Środowiska (European Environment Agency - EEA);

- green growth - określenie stosowane przez Organizację Współpracy Gospodarczej i Rozwoju (Organization for Economic Co-operation and Development-OECD).

Pojęcie zielonej gospodarki, które ściśle jest powiązane z koncepcją zrównoważonego rozwoju, rozwinęło się stosunkowo niedawno, kiedy to w 2008 roku UNEP wezwał do podjęcia Inicjatywy Zielonej Gospodarki (Green Economy Initiative), znanej jako Globalny Zielony Nowy Ład (Global Green New Deal), dostrzegając możliwości i szanse na wyjście z ogólnoświatowego kryzysu gospodarczego dzięki rozwojowi sektorów zielonej gospodarki. W wydanym, w marcu 2009 roku raporcie Global Green New Deal. Policy Brief (Globalmy Zielony Nony Lad. Streszczenie polityk) zarekomendowano inwestycje w obszarach kluczowych dla środowiska i jednocześnie tych, które mają największy potencjał w procesie transformacji w kierunku zielonej gospodarki, takich jak:

- energia odnawialna,

- czyste technologie,

- budownictwo wydajne energetycznie (energooszczędne),

- transport publiczny,

- gospodarka odpadami i recykling,

- zrównoważone wykorzystanie: gruntów, wody, lasów, łowisk morskich,

- ekoturystyka.

Wraz z rozwojem inicjatyw budowania zielonej gospodarki pojawia się konieczność wykształcenia metod monitorowania i oceny stopnia jej zazielenienia. Rzetelne, właściwie dobrane i aktualne dane o stanie zazielenienia gospodarki są istotnym elementem wdrażania polityk ochrony środowiska, stosowania instrumentów gospodarczych (np.: podatków, dotacji) czy też działań pobudzających innowacje ekologiczne $\mathrm{i}$ inwestycje $\mathrm{w}$ zielone technologie oraz monitorowania skuteczności tych działań. Dane te powinny dostarczać cennych informacji na temat konkretnych wyzwań stojacych przed decydentami, a prezentowane w szerszym kontekście, umożliwić śledzenie zmian zachodzących w: gospodarce, środowisku i społeczeństwie. Uwzględniając do- 
tychczasowe podejścia ugrupowań międzynarodowych oraz doświadczenia krajów w monitorowaniu zielonej gospodarki, w Polsce także podjęto przygotowania do opracowania metodologii jej pomiaru. Celem niniejszego artykułu jest przedstawienie ujęcia oraz wskaźników pomiaru zielonej gospodarki będących dorobkiem trzech organizacji międzynarodowych, a mianowicie: UNEP, EEA i OECD.

\section{Ujęcie i monitorowanie zielonej gospodarki przez Program Środowiskowy Narodów Zjednoczonych - UNEP}

W 2011 roku UNEP opublikował raport Towards a Green Economy, w którym zauważa z jednej strony, że wzrost oparty na „brązowym” modelu gospodarki bazującej na paliwach kopalnych nie rozwiązał zasadniczo problemów marginalizacji społecznej, zanieczyszczenia środowiska oraz wyczerpywania zasobów, natomiast z drugiej, że zazielenianie gospodarki nie jest bariera, ale raczej motorem rozwoju gospodarczego, tworzącym godne warunki pracy czy eliminującym ubóstwo. Przygotowane opracowanie miało na celu zmotywowanie decydentów poszczególnych krajów do tworzenia sprzyjających warunków do zwiększonych inwestycji ukierunkowanych w stronę zielonej gospodarki [Towards a Green Economy: Pathways..., 2011, s. 16-17].

Program Środowiskowy Narodów Zjednoczonych (UNEP) definiuje zieloną gospodarkę jako tę, która znacznie ogranicza degradację środowiska oraz przyczynia się do poprawy dobrobytu człowieka i sprawiedliwości społecznej. Innymi słowy, zielona gospodarka to gospodarka niskoemisyjna, efektywnie korzystająca z zasobów i sprzyjająca włączeniu społecznemu. Zwolennicy zielonej gospodarki kładą nacisk na przesunięcie działań politycznych oraz inwestycji publicznych i prywatnych w kierunku: czystych technologii, wzmocnienia usług ekosystemów i bazy zasobów naturalnych, edukacji, służby zdrowia $\mathrm{i}$ instytucji w celu zapewnienia ochrony socjalnej i sprawiedliwości społecznej. W zielonej gospodarce wzrost dochodów i zatrudnienia jest osiagany przez działania polityczne oraz publiczne i prywatne inwestycje zmniejszające emisję zanieczyszczeń, zwiększające efektywność wykorzystania energii i zasobów, a także zapobiegające utracie bioróżnorodności i zdolności usługowych ekosystemu [Measuring Progress..., 2012, s. 9-11].

Zielona gospodarkę uznano za ważne narzędzie umożliwiające osiagnięcie zrównoważonego rozwoju (a nie za cel sam w sobie), a wskaźniki zielonej gospodarki za użyteczne w procesach decyzyjnych władz publicznych. W grudniu 2012 roku UNEP opublikował dokument ramowy pt.: Measuring Progress towards an Inclusive Green Economy, który ma służyć lepszemu zrozumieniu i wykorzystaniu wskaźników zielonej gospodarki w celu szczególnego wsparcia polityk zielonej gospodarki. Gromadzenie i analiza danych ma bowiem decydujące znaczenie dla oceny skuteczności tych polityk (polityk zielonej gospodarki), a wskaźniki są niezbędne, aby zwrócić uwagę na kwestie priorytetowe, wyznaczać cele i monitorować postęp (rezultaty tych polityk), [Measuring Progress..., 2012, s. 9].

Program Środowiskowy Narodów Zjednoczonych (UNEP), jako agenda ONZ w zakresie ochrony środowiska i stałego monitorowania jego stanu na świecie, za punkt wyjścia do monitorowania zielonej gospodarki przyjmuje środowisko. Gospodarka bowiem nie może stać się zielona bez wcześniejszego rozwiązania problemów środowiskowych. Pomiar zielonej gospodarki nie musi koncentrować się tylko na ocenie stanu 
zielonej gospodarki, ale również może być dokonywany z perspektywy kształtowania polityk zielonej gospodarki (tabela 1.), [Measuring Progress..., 2012, s. 13].

TABELA 1.

Grupy wskaźników znajdujące zastosowanie na różnych etapach realizacji polityk zielonej gospodarki

\begin{tabular}{|c|c|}
\hline Etap wstępny & Wskaźniki zagadnień i celów środowiskowych \\
Initial stages & Indicators for environmental issues and targets \\
\hline Etap pośredni & Wskaźniki interwencji w ramach polityk zielonej gospodarki \\
Intermediary stages & Indicators for policy interventions \\
\hline Etap końcowy & Wskaźniki wpływu polityk zielonej gospodarki na dobrobyt i sprawiedliwość \\
Final stages & Indicators for policy impacts on well-being and equity \\
\hline
\end{tabular}

Źródło: [Measuring Progress..., 2012, s. 12].

Wskaźniki zielonej gospodarki w zakresie rozwoju polityk i śledzenia ich realizacji można podzielić na trzy główne kategorie:

1) wskaźniki zagadnień i celów środowiskowych, które mają być uwzględnione w politykach zielonej gospodarki; obejmują one takie obszary tematyczne, jak: zmiany klimatu, zarządzanie ekosystemami, efektywne wykorzystanie zasobów oraz gospodarowanie odpadami. Do pomiaru każdego z tych obszarów można zastosować kilka głównych wskaźników (tabela 2.);

TABELA 2.

Przykładowe zagadnienia środowiskowe i powiązane z nimi wskaźniki

\begin{tabular}{|c|c|}
\hline Zagadnienia & Wskaźniki \\
\hline $\begin{array}{l}\text { Zmiany klimatyczne } \\
\text { Climate change }\end{array}$ & $\begin{array}{l}\text { - Emisja dwutlenku węgla (t/r.) } \\
\text { Carbon emissions (ton/year) } \\
\text { - Odnawialne źródła energii (udział w podaży energii), (\%) } \\
\text { Renewable energy (share of power supply), (\%) } \\
\text { - Zużycie energii na osobę (jednostka energii/osoba) } \\
\text { Energy consumption per capita (Btu/person) }\end{array}$ \\
\hline $\begin{array}{c}\text { Zarządzanie ekosyste- } \\
\text { mami } \\
\text { Ecosystem manage- } \\
\text { ment }\end{array}$ & $\begin{array}{l}\text { - Obszary leśne (ha) } \\
\text { Forestland (ba) } \\
\text { - Stres wodny (\%) } \\
\text { Water stress }(\%) \\
\text { - Grunty i ochrona obszarów morskich (ha) } \\
\quad \text { Land and marine conservation area }(\mathrm{ba}) \\
\end{array}$ \\
\hline $\begin{array}{l}\text { Wydajność zasobów } \\
\text { Resource efficiency }\end{array}$ & $\begin{array}{l}\text { - Wydajność energii (jednostka energii/dol.) } \\
\text { Energy productivity (Btu/USD) } \\
\text { - Wydajność surowców (t/dol.) } \\
\text { Material productivity (ton/USD) } \\
\text { - } \quad \text { Wydajność wody (m3/dol.) } \\
\text { Water productivity (m3/USD) } \\
\text { - } \quad \text { Wydajność CO } \mathrm{CO}_{2}(\mathrm{t} / \mathrm{dol} \text {.) } \\
\mathrm{CO}_{2} \text { productivity (ton/USD) }\end{array}$ \\
\hline $\begin{array}{c}\text { Substancje chemiczne i } \\
\text { gospodarka odpadami } \\
\text { Chemicals and waste } \\
\text { management }\end{array}$ & $\begin{array}{l}\text { - Odpady zebrane }(\%) \\
\text { Waste collection (\%) } \\
\text { - Recykling i ponowne wykorzystanie odpadów (\%) } \\
\text { Waste recycling and reuse }(\%) \\
\text { - Wytworzone odpady }(\mathrm{t} / \mathrm{r} \text {.) lub składowiska (ha) } \\
\text { Waste generation (ton/year) or landfill area (ba) }\end{array}$ \\
\hline
\end{tabular}

Źródło: [Measuring Progress..., 2012, s. 15]. 
2) wskaźniki interwencji w ramach polityk zielonej gospodarki - w momencie, gdy cele są ustanowione, niezbędne jest podjęcie działań politycznych, tworzących bodźce umożliwiające osiagnięcie pożądanego efektu w postaci: zmniejszenia degradacji środowiska, poprawy dobrobytu ludzi i sprawiedliwości społecznej. W zielonej gospodarce kluczowym instrumentem polityk jest przesunięcie inwestycji w kierunku zielonych działań, wsparte przez: reformy fiskalne, polityki cenowe, zamówienia publiczne oraz szkolenia z zakresu zielonych umiejętności (tabela 3.);

TABELA 3.

Przykładowe obszary interwencji polityk zielonej gospodarki i powiązane z nimi wskaźniki

\begin{tabular}{|c|c|}
\hline Obszary interwencji & Wskaźniki \\
\hline $\begin{array}{l}\text { Zielone inwestycje } \\
\text { Green investment }\end{array}$ & $\begin{array}{l}\text { - Nakłady na } \mathrm{B}+\mathrm{R}(\% \mathrm{PKB}) \\
\text { RED investment }(\% \text { of GDP) } \\
\text { - Inwestycje sektora dóbr i usług środowiskowych (dol./r.) } \\
\text { EGSS investment (USD/year) }\end{array}$ \\
\hline $\begin{array}{c}\text { Zielona reforma podatkowa } \\
\text { Green fiscal reform }\end{array}$ & $\begin{array}{l}\text { - Dotacje w zakresie paliw kopalnianych, wody i rybołówstwa (dol. lub } \\
\% \text { ) } \\
\text { Fossil fuel, water and fishery subsidies (USD or \%) } \\
\text { - Opodatkowanie paliw kopalnych (dol. lub \%) } \\
\text { Fossil fuel taxation (USD or \%) } \\
\text { - Dopłaty do wykorzystywania energii odnawialnej (dol. lub \%) } \\
\text { Renewable energy incentive (USD or \%) }\end{array}$ \\
\hline $\begin{array}{l}\text { Cenowe efekty zewnętrzne } \\
\text { i wycena usług ekosystemowych } \\
\text { Pricing externalities and valu- } \\
\text { ing ecosystem service }\end{array}$ & $\begin{array}{l}\text { - Cena węgla (dol./t) } \\
\text { Carbon price (USD/ton) } \\
\text { - Wartość usług ekosystemowych (np. zaopatrzenia w wodę) } \\
\text { Value of ecosystem services (e.g., water provision) }\end{array}$ \\
\hline $\begin{array}{l}\text { Zielone zamówienia publiczne } \\
\text { Green procurement }\end{array}$ & $\begin{array}{l}\text { - Wydatki na zrównoważone zamówienia (dol./r. i \%) } \\
\text { Expenditure in sustainable procurement (USD/year and \%) } \\
\text { - Wydajność } \mathrm{CO}_{2} \text { i surowców w wyniku interwencji rządowych } \\
\text { (t/dol.) } \\
\mathrm{CO}_{2} \text { and material productivity of government operations (ton/USD) }\end{array}$ \\
\hline $\begin{array}{l}\text { Szkolenia z zakresu zielonych } \\
\text { umiejętności } \\
\text { Green job skill training }\end{array}$ & $\begin{array}{l}\text { - Wydatki na szkolenia (dol./r. i \% PKB) } \\
\text { Training expenditure (USD/year and \% of GDP) } \\
\text { - Liczba przeszkolonych osób (osoba/r.) } \\
\text { Number of people trained (person/year) }\end{array}$ \\
\hline
\end{tabular}

Źródło: [Measuring Progress..., 2012, s. 17].

3) wskaźniki wpływu polityk zielonej gospodarki na dobrobyt i sprawiedliwość - za pomocą wskaźników ekonomicznych scharakteryzowano w tej grupie takie obszary tematyczne, jak: zatrudnienie, wydajność sektora dóbr i usług środowiskowych (EGSS - environmental goods and service sector), kapitał naturalny i ludzki, dostęp do zasobów (np.: czystej energii, wody i urządzeń sanitarnych) oraz zdrowie (tabela 4.). 
TABELA 4.

Przykładowe obszary mające wpływ na dobrobyt i sprawiedliwość oraz powiązane z nimi wskaźniki ekonomiczne

\begin{tabular}{|c|c|}
\hline Obszary & Wskaźniki \\
\hline $\begin{array}{l}\text { Zatrudnienie } \\
\text { Employment }\end{array}$ & $\begin{array}{l}\text { - Struktura zatrudnienia (osoby, \%) } \\
\text { Construction (person, \%) } \\
\text { - Obsługa i zarządzanie (osoby, \%) } \\
\text { Operation and management (person, \%) } \\
\text { - } \quad \text { Dochód wytworzony (dol./r.) } \\
\text { Income generated (USD/year) } \\
\text { - Współczynnik Giniego } \\
\text { Gini coefficient } \\
\end{array}$ \\
\hline $\begin{array}{c}\text { Wydajność sektora dóbr i usług } \\
\text { środowiskowych } \\
\text { EGSS performance }\end{array}$ & $\begin{array}{l}\text { - Wartość dodana (dol./r.) } \\
\text { Value added (USD/year) } \\
\text { - Zatrudnienie (miejsca pracy) } \\
\text { Employment (jobs) } \\
\text { - } \quad \text { Wydajność } \mathrm{CO}_{2} \text { i surowców (np. dol./t) } \\
\text { CO } \mathrm{O}_{2} \text { and material productivity (e.g., USD/ton) } \\
\end{array}$ \\
\hline $\begin{array}{c}\text { Bogactwo ogólne - kapitał na- } \\
\text { turalny i ludzki } \\
\text { Total wealth }\end{array}$ & $\begin{array}{l}\text { - Wartość zapasów zasobów naturalnych (dol.) } \\
\text { Value of natural resource stocks (USD) } \\
\text { - Roczna wartość dodana netto / zlikwidowana (dol./r.) } \\
\text { Net annual value addition/ removal (USD/year) } \\
\text { - Analfabetyzm (\%) } \\
\text { Literacy rate (\%) }\end{array}$ \\
\hline $\begin{array}{l}\text { Dostęp do zasobów } \\
\text { Access to resources }\end{array}$ & $\begin{array}{l}\text { - Dostęp do nowoczesnych źródeł energii (\%) } \\
\text { Access to modern energy }(\%) \\
\text { - Dostęp do wody }(\%) \\
\text { Access to water }(\%) \\
\text { - Dostęp do urządzeń sanitarnych }(\%) \\
\text { Access to sanitation }(\%) \\
\text { - Dostęp do opieki zdrowotnej }(\%) \\
\text { Access to bealth care }(\%) \\
\end{array}$ \\
\hline $\begin{array}{c}\text { Zdrowie } \\
\text { Health }\end{array}$ & $\begin{array}{l}\text { - Poziom szkodliwych substancji chemicznych w wodzie pitnej (g/litr) } \\
\text { Level of harmful chemicals in drinking water (g/litre) } \\
\text { - Hospitalizowani z powodu zanieczyszczeń powietrza (osoby) } \\
\text { Number of people hospitalized due to air pollution (person) } \\
\text { - Ofiary śmiertelne w wypadkach drogowych na } 100 \text { tys. mieszkańców } \\
\text { Road traffic fatalities per } 100000 \text { inhabitants (transport related) }\end{array}$ \\
\hline
\end{tabular}

Źródło: [Measuring Progress..., 2012, s. 20].

Program Środowiskowy Narodów Zjednoczonych (UNEP) podkreśla, że właściwe ramy pomiaru zielonej gospodarki oraz gromadzenie danych i ich analiza mają decydujące znaczenie dla zaspokojenia potrzeb decydentów z zakresu monitorowania postępu i oceny skuteczności podejmowanych polityk zielonej gospodarki. Program Środowiskowy Narodów Zjednoczonych (UNEP) świadczy usługi doradcze z zakresu zielonej gospodarki w ponad 20 krajach, w Afryce, Azji i na Pacyfiku, w Europie Wschodniej, Ameryce Łacińskiej i na Karaibach. Obejmują one doradztwo w obszarze: wdrażania polityk, pomocy technicznej i budowania potencjału krajów w celu wsparcia krajowych i regionalnych wysiłków na rzecz przekształcenia i ożywienia gospodarek poszczególnych państw. Program Środowiskowy Narodów Zjednoczonych (UNEP) pomaga krajom określić konkretne wskaźniki, jak również wspiera rozwój krajowych ram 
statystycznych, które umożliwią śledzenie postępu w kierunku przejścia na zielona gospodarkę [Measuring Progress..., 2012, s. 29].

\section{Monitorowanie zielonej gospodarki według Europejskiej Agencji Środowiska (EEA)}

Według Europejskiej Agencji Środowiska, zielona gospodarka to gospodarka, w której polityka: środowiskowa, gospodarcza, społeczna oraz innowacje zapewniaja społeczeństwu efektywne wykorzystanie zasobów w procesach produkcji i konsumpcji, a tym samym stanowią potencjał do zwiększenia dobrobytu człowieka w sposób kompleksowy, przy jednoczesnym zachowaniu stabilności systemów naturalnych [Environmental Indicator Report..., 2012, s. 17]. U podstaw transformacji do zielonej gospodarki leży integracja polityk gospodarczych i środowiskowych w celu stworzenia nowych źródeł rozwoju gospodarczego, przy jednoczesnym unikaniu niezrównoważonego nacisku na ilość i jakość kapitału naturalnego. Jednocześnie taka transformacja ma potencjał, który służy wzmocnieniu kapitału społecznego i sprawiedliwego podziału obciążeń w projektowaniu polityk, sprawiedliwemu podziału kosztów ochrony środowiska i sprawiedliwemu dostępu do korzyści środowiskowych. Zielona gospodarka może stworzyć kolejne możliwości, w szczególności w zakresie nowych miejsc pracy w wielu sektorach gospodarki lub przez przeniesienie miejsc pracy z działalności opartej na zasobach nieodnawialnych (takich jak paliwa kopalne) do tej, która wykorzystuje zasoby odnawialne (np. działalność związana z recyklingiem). Przejście do zielonej gospodarki jest uzależnione w znacznym zakresie od: inwestycji (np. w zielone technologie), wykorzystania innowacji (zwłaszcza innowacji ekologicznych) i zaangażowania obywateli [Environmental Indicator Report..., 2012, s. 24-25].

Europejska Agencja Środowiska (EEA) zauważa, że potrzeba transformacji gospodarki na zielona jest kluczowym priorytetem ochrony środowiska, a elementy składowe zielonej gospodarki, takie jak: ekosystemy, gospodarka i dobrobyt ludzi oraz związane z nimi określone rodzaje kapitału sa ze sobą ściśle powiązane (rysunek 1.), [Environmental Indicator Report..., 2012, s. 19].

Według EEA, u podstaw zielonej gospodarki leży podwójne wyzwanie:

1) W odniesieniu do gospodarki - poprawa efektywności wykorzystywania zasobów, a więc konieczne jest znalezienie sposobów na zwiększenie dobrobytu społeczeństwa bez zwiększania zużycia zasobów i negatywnego wpływu na środowisko. Jednak samo efektywne wykorzystanie zasobów nie gwarantuje osiagnięcia zrównoważonego rozwoju;

2) W odniesieniu do ekosystemów - konieczne jest zapewnienie ich odporności, aby stale były zdolne dostarczać człowiekowi usługi środowiskowe. Odporność ekosystemu jest definiowana jako umiejętność ekosystemów do tolerowania zakłóceń (zagrożeń) środowiskowych, wywołanych działalnością człowieka bez przechodzenia w inny jakościowo stan. Działalność człowieka, która negatywnie oddziałuje na odporność ekosystemów, to ta, która prowadzi do: zmiany klimatu, zanieczyszczenia, utraty bioróżnorodności, nadmiernej eksploa- 
tacji zasobów naturalnych w celu pobudzania gospodarki [Environmental Indicator Report..., 2012, s. 17].

\section{Elementy zielonej gospodarki}

\section{RYSUNEK 1.}

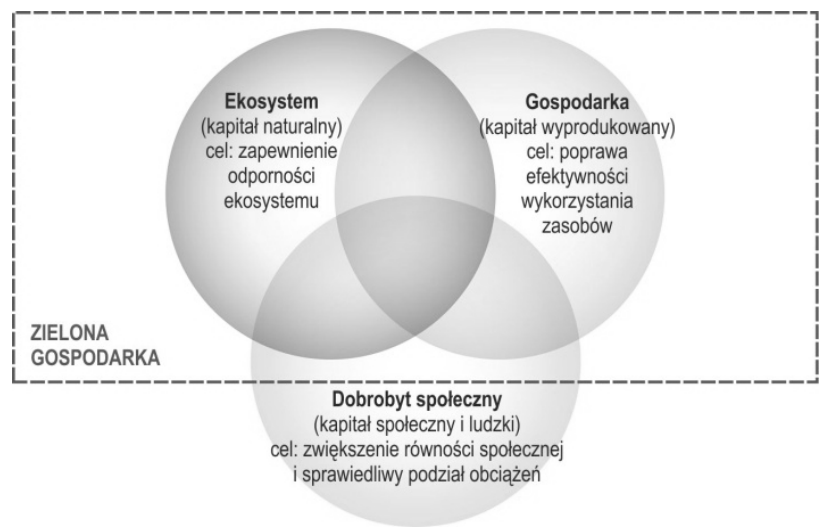

Źródło: [Environmental Indicator Report..., 2012, s. 20].

Obok poprawy efektywności wykorzystania zasobów i zapewnienia odporności ekosystemów, istnieje wyraźna konieczność włączenia trzeciego aspektu, jakim jest dobrobyt człowieka. Element ten jest ważny, ponieważ korzyści, jakie czerpie się ze środowiska i szkody, które są odczuwane z powodu jego degradacji, nie zawsze znajdują odzwierciedlenie w cenach rynkowych, a zatem wymagają oddzielnego rozważenia. Istnieje zatem potrzeba zapewnienia sprawiedliwego podziału korzyści i kosztów restrukturyzacji gospodarek [Towards a Green Economy..., 2013, s. 5].

W ciagu ostatnich 20 lat EEA opublikowała wskaźniki z zakresu większości europejskich kwestii środowiskowych. Dziś utrzymuje obszerny zbiór ponad 200 wskaźników środowiskowych w 12 środowiskowych obszarach tematycznych (rysunek 2.). Większość z tych wskaźników (stworzonych na podstawie danych zebranych przez EEA i inne organizacje międzynarodowe) jest zaprojektowana w celu wspierania polityk z zakresu ochrony środowiska [Towards a Green Economy..., 2013, s. 27].

W raporcie Environmental Indicator Report 2012. Ecosystem Resilience and Resource Efficiency in a Green Economy in Europe, EEA dokonuje oceny postępów w zakresie zapewnienia odporności ekosystemów oraz poprawy efektywności wykorzystywania zasobów, opartej na zestawie wskaźników środowiskowych w ramach sześciu grup tematycznych dotyczących [Environmental Indicator Report..., 2012, s. 9]:

- utraty bioróżnorodności i emisji azotu;

- zmiany klimatu i emisji dwutlenku węgla,

- jakości powietrza i jego zanieczyszczenia,

- ochrony środowiska morskiego i jego wykorzystania,

- $\quad$ stresu wodnego i zużycia wody,

- gospodarowania odpadami i wykorzystania zasobów. 
RYSUNEK 2.

\section{Obszary tematyczne wskaźników środowiskowych EEA}

Źródło: [Environmental Indicator Report..., 2012, s. 29].

W ramach każdego z obszarów tematycznych EEA koncentruje się na dwóch rodzajach wskaźników środowiskowych w kontekście zielonej gospodarki, tj.:

1. Wskaźnikach opisujących stan lub oddziaływanie na środowisko, pomagających zilustrować zagrożenia dla odporności ekosystemów, np.: siedliska o znaczeniu europejskim, temperatury światowe i europejskie, emisja prekursorów ozonu, wskaźnik eksploatacji wody, ślad ekologiczny;

2. Wskaźnikach, które przedstawiaja presję na środowisko i postęp w poprawie efektywności wykorzystania zasobów, np.: emisja substancji zakwaszających, emisje prekursorów pyłu pierwotnego i wtórnego, efektywność energetyczna, wykorzystanie zasobów wody słodkiej (pobór wody przez różne sektory) [Environmental Indicator Report..., 2012, s. 31].

\section{Stanowisko Organizacji Współpracy Gospodarczej i Rozwoju (OECD) w zakresie monitorowania zielonej gospodarki}

Rada OECD w czerwcu 2009 roku podjęła decyzję w sprawie opracowania strategii zielonego wzrostu, która ma służyć wspieraniu zielonych inwestycji i innowacji technologicznych, tak aby w perspektywie krótkoterminowej przyczynić się do ożywienia gospodarczego, a w długim horyzoncie czasowym pomóc zbudować infrastrukturę 
przyjazną środowisku, potrzebną do osiagnięcia pożądanego poziomu zazielenienia gospodarki [Korea Institute for International Economic Policy, 2013, s. 211]. W 2011 roku OECD ogłosiła zestaw wskaźników w celu statystycznego wsparcia oceny efektów realizacji strategii. Uznano bowiem, iż produkt krajowy brutto (PKB) jako podstawowy miernik dochodu narodowego, nie może być jedynym wskaźnikiem określającym dobrobyt społeczeństwa i poziom zazielenienia gospodarki, ponieważ pomiary koncentrujące się tylko na PKB są niekompletne. Nie uwzględniają one przede wszystkim roli, jaką w systemach produkcji odgrywaja czynniki związane ze środowiskiem naturalnym. Dodatkowo, Rada OECD zaproponowała, aby każdy kraj członkowski przygotował wskaźniki dostosowane do jego sytuacji społeczno-gospodarczej, bazujące na dorobku OECD [Towards Green Growth..., 2011, s. 9].

Według OECD, zielony wzrost polega na podejmowaniu działań wspierających wzrost i rozwój gospodarczy, przy jednoczesnym zapewnieniu, że kapitał naturalny (zasoby naturalne i jakość środowiska), od którego zależy dobrobyt ludności, nie zostanie nadmiernie wykorzystany [Towards Green Growth..., 2011, s. 9]. Konieczne jest więc pobudzanie zielonych inwestycji i innowacji stanowiących podstawę trwałego wzrostu gospodarczego i nowych możliwości gospodarczych. Zielony wzrost oznacza taki, który uwzględnia oszczędność zasobów i energii oraz ich wydajne wykorzystanie w celu ograniczenia zmian klimatu oraz zanieczyszczenia środowiska naturalnego, następujacych w wyniku wprowadzenia nowych motorów wzrostu dzięki badaniom i rozwojowi zielonych technologii, tworzeniu zielonych miejsc pracy, a w efekcie prowadzących do osiagnięcia stanu zielonej gospodarki zapewniającej harmonię między gospodarką a środowiskiem.

W raporcie wskaźnikowym, zatytułowanym Towards Green Growth: Monitoring Progress. OECD Indicators, OECD zaproponowała monitorowanie postępu w zazielenianiu gospodarki, oparte na czterech grupach wskaźników. Każdej grupie przypisano zestaw wskaźników, które powinny służyć opisowi i ocenie stopnia zazielenienia gospodarki.

Relacje, jakie zachodza pomiędzy zidentyfikowanymi elementami zielonej gospodarki i grupami wskaźników, według OECD, zaprezentowano na rysunku 3.

Sfera produkcji jest punktem wyjścia do wyodrębnienia pierwszej grupy wskaźników zielonej gospodarki. W procesach produkcji następuje wykorzystanie zasobów środowiska, a także pracy i kapitału w celu wytworzenia wyrobów oraz usług. Efektem produkcji, obok dochodu, dóbr i usług, są również pozostałości w postaci odpadów i zanieczyszczeń, a środowisko wykorzystuje się jako miejsce ich składowania i absorpcji. Podstawowy priorytet w procesie zazieleniania gospodarki stanowi zwiększenie efektywności wykorzystania walorów środowiska naturalnego i zasobów naturalnych. Jego celem jest zerwanie zależności między wzrostem gospodarczym a zwiększonym wykorzystaniem zasobów naturalnych. Efektywność ta oraz jej zmiany w czasie są najczęściej stosowanymi miernikami zielonego wzrostu [Towards Green Growth..., 2011, s. 51]. Postęp w kierunku zazieleniania gospodarki może być monitorowany przez odnoszenie wygenerowanej produkcji do wykorzystania usług środowiskowych oraz śledzenie trendów decouplingu (rysunek 4.), czyli zerwanie zależności pomiędzy produkcją a usługami środowiskowymi. Może ono mieć charakter względny lub bezwzględny (całkowity). Względne zerwanie zależności (relative decoupling) występuje wówczas, gdy intensywność 
wykorzystania zasobów środowiska (presja na środowisko) rośnie, ale wolniej niż tempo wzrostu zmiennej gospodarczej (np.: PKB, wartość dodana). Ostatecznym celem zielonej gospodarki jest osiąnnięcie całkowitego zerwania zależności (absolute decoupling), czyli stanu, kiedy produkcja gospodarcza rośnie, a wykorzystanie usług środowiskowych utrzymuje się na tym samym poziomie lub wykazuje bezwzględny spadek [Green Growth in the Netherlands, 2011, s. 14-15]. Wzrost efektywności wykorzystania środowiska naturalnego jest koniecznym warunkiem w procesach zazieleniania gospodarki. Efektywne gospodarowanie zasobami naturalnymi oraz odpadami powinno bowiem prowadzić do redukcji negatywnego wpływu na środowisko naturalne.

W ramach pierwszej grupy wskaźników, monitorujących efektywność wykorzystania walorów środowiska naturalnego i zasobów naturalnych, OECD zaproponowało zestaw wskaźników zawartych w tabeli 5.

RYSUNEK 3.

Relacje między elementami zielonej gospodarki i grupami wskaźników OECD

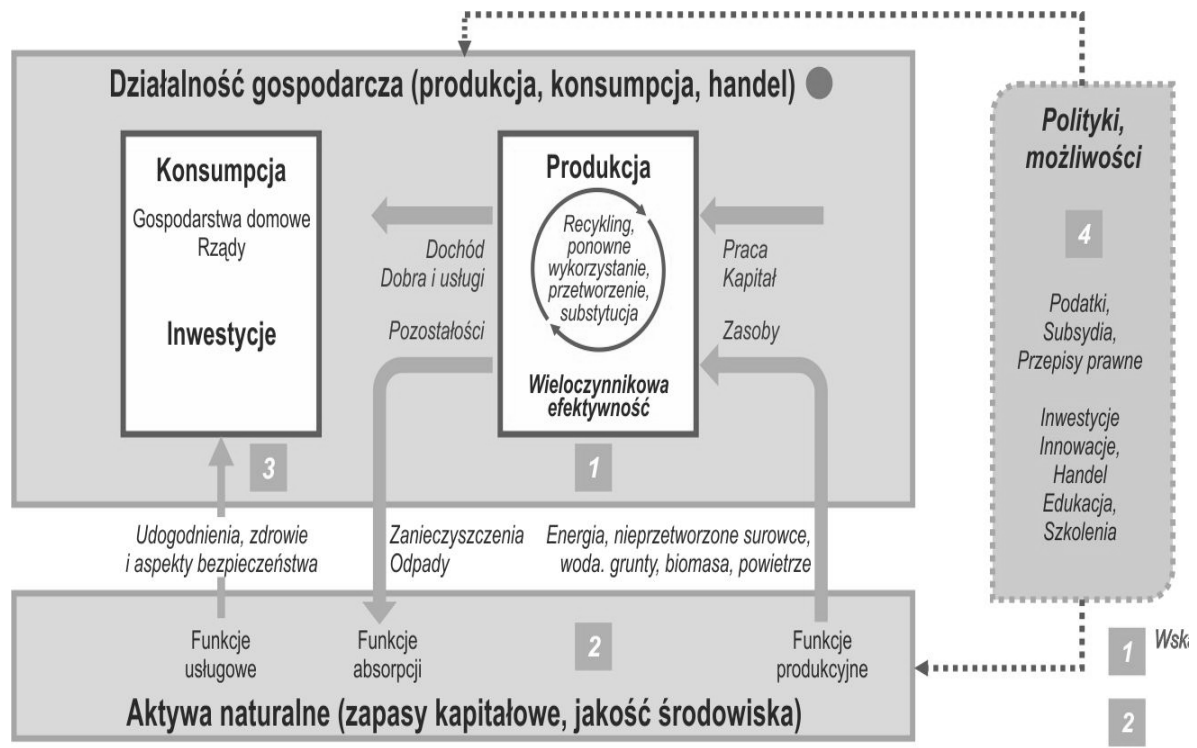

1 Wskaźniki monitonjące efektywności wykorzystania

walorów środowiska naturalnego i zasobów naturalnych

2 Wskaźniki monitonjące aktywa naturalne

3 Wskaźniki monitorujące środowiskową jakość życia

4 Wskaźniki monitorujące reakcje polityczne

i moźliwości gospodarcze

Uwarunkowania spoleczno-gospodarcze

Źródło: [Monitoring Progress..., 2013, s. 6]. 
RYSUNEK 4. Względne i całkowite zerwanie zależności (relative i absolute decoupling)

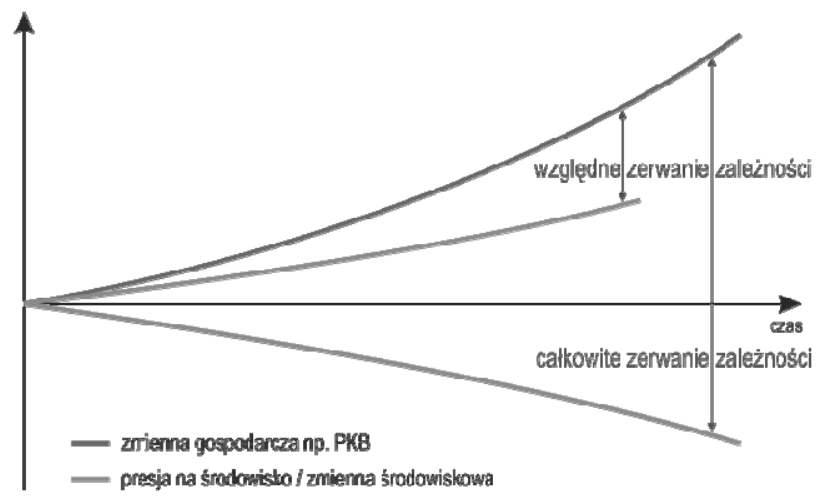

Źródło: [Environmental Indicator Report..., 2012, s. 23].

Aktywa naturalne (Natural asset base), obejmujące zapasy zasobów odnawialnych i nieodnawialnych, maja $\mathrm{w}$ zielonej gospodarce podstawowe znaczenie, ponieważ presja na ich wykorzystanie rośnie w sposób nieunikniony i w efekcie uniemożliwia utrzymanie obecnej ścieżki wzrostu gospodarczego. Stała eksploatacja ziemi ponad jej możliwości może doprowadzić do nieodwracalnych strat i spowodować zachwianie równowagi aktywów naturalnych. Celem zielonego wzrostu jest zapewnienie, wystarczającego dla rozwoju gospodarczego, zaopatrzenia w zasoby odnawialne i nieodnawialne oraz pozostałe usługi ekosystemowe, przy równoczesnym minimalizowaniu niekorzystnego wpływu na środowisko, który jest związany z ich: pozyskiwaniem, wykorzystywaniem i przetwarzaniem. Z perspektywy zielonego wzrostu istotne jest, aby wskaźniki monitorujące odnosiły się do zasobów i usług istotnych dla ekonomicznego wzrostu i rozwoju zarówno pod względem ilościowym, jak i jakościowym [Towards Green Growth..., 2011]. Zestaw wskaźników, proponowanych przez OECD do monitorowania aktywów naturalnych, zaprezentowano w tabeli 6 .

Kolejnym elementem, podlegającym obserwacji, jest środowiskowa jakość życia, która wiąże się z usługami: regulacyjnymi, przestrzeni życiowej, kulturowymi, jakie środowisko naturalne świadczy ludziom i z ogólnym stanem środowiska naturalnego. Jakość środowiska jest kluczowym czynnikiem, który rzutuje na ogólny dobrobyt ludzi oraz innych istot żywych. Poziom zanieczyszczeń środowiska wpływa bezpośrednio na jakość życia ludności wskutek oddziaływania na stan zdrowia społeczeństwa. Wskaźniki, dotyczące środowiskowej jakości życia, odnoszą się do ekspozycji ludności na różne zanieczyszczenia środowiska i związane z nim skutki zdrowotne oraz łączą się z dostępem ludności do podstawowych usług służących ochronie środowiska, np. podłączenie do sieci wodociagowej zapewniającej dostęp do czystej wody i kanalizacyjnej, odprowadzającej ścieki do oczyszczalni. Te obiektywne wskaźniki pomiaru powinny zostać uzupełnione o miary subiektywne, określające poglądy ludzi na temat jakości środowiska, w którym żyją [Towards Green Growth..., 2011, s. 27]. Ich zestawienie, zaproponowane do monitorowania przez OECD, przedstawiono w tabeli 7. 
TABELA 5.

\section{Wskaźniki efektywności wykorzystania walorów środowiska naturalnego} i zasobów naturalnych

\begin{tabular}{|c|c|}
\hline $\begin{array}{l}\text { Grupa/zagadnienia } \\
\text { Group/theme }\end{array}$ & $\begin{array}{c}\text { Proponowane wskaźniki } \\
\text { Proposed indicators }\end{array}$ \\
\hline \multicolumn{2}{|c|}{$\begin{array}{c}\text { Efektywność wykorzystania walorów środowiska naturalnego i zasobów naturalnych } \\
\text { Environmental and resource productivity }\end{array}$} \\
\hline $\begin{array}{l}\text { Wydajność węgla } \\
\text { i energii } \\
\text { Carbon \& energy } \\
\text { productivity }\end{array}$ & $\begin{array}{l}\text { 1. Wydajność } \mathbf{C O}_{2} \\
\boldsymbol{C O}_{2} \text { productivity } \\
\text { 1.1. Wydajność } \mathrm{CO}_{2} \text { oparta na produkcji } \\
\text { PKB na jednostkę wyemitowanego } \mathrm{CO}_{2} \text { związanego z energią } \\
\text { Production-based } \mathrm{CO}_{2} \text { productivity } \\
\text { GDP per unit of energy-related } \mathrm{CO}_{2} \text { emitted } \\
\text { 1.2. Wydajność } \mathrm{CO}_{2} \text { oparta na popycie } \\
\text { Dochód realny na jednostkę wyemitowanego } \mathrm{CO}_{2} \text { związanego z energią } \\
\text { Demand-based } \mathrm{CO}_{2} \text { productivity } \\
\text { Real income per unit of energy-related } \mathrm{CO}_{2} \text { emitted } \\
\text { Wydajność energii } \\
\text { Energy productivity } \\
\text { 2.1. Wydajność energii (PKB na jednostkę całkowitej podaży energii pierwotnej) } \\
\text { Energy productivity (GDP per unit of TPES) } \\
\text { 2.2. Energochłonność według sektorów (produkcja, transport, gospodarstwa domowe, } \\
\text { usługi) } \\
\text { Energy intensity by sector (manufacturing, transport, bouseholds, services) } \\
\text { 2.3. Udział energii odnawialnej w całkowitej podaży energii pierwotnej, w produkcji } \\
\text { energii elektrycznej } \\
\text { Share of renewable energy in TPES, in electricity production }\end{array}$ \\
\hline $\begin{array}{l}\text { Wydajność zaso- } \\
\text { bów } \\
\text { Resource pro- } \\
\text { ductivity }\end{array}$ & $\begin{array}{l}\text { 3. Wydajność surowców (nieenergetycznych) } \\
\text { Material productivity (non-energy) } \\
\text { 3.1. Wydajność surowców oparta na popycie (miara kompleksowa; oryginalne jednostki } \\
\text { w sensie fizycznym) związanym z realnym dochodem rozporządzalnym } \\
\text { Demand based material productivity (comprehensive measure; original units } \\
\text { in physical terms) related to real disposable income } \\
\text { - Krajowa wydajność surowców (PKB/krajowa konsumpcja surowców) } \\
\text { - Surowce biotyczne (żywność, pozostała biomasa) } \\
\text { - Surowce abiotyczne (minerały metaliczne, przemysłowe) } \\
\text { Domestic material productivity (GDP/DMC) } \\
\text { - Biotic materials (food, other biomass) } \\
\text { - Abiotic materials (metallic minerals, industrial minerals) } \\
\text { Intensywność wytwarzania odpadów i wskaźniki odzysku } \\
\text { Według sektorów, na jednostkę PKB lub wartości dodanej, na } 1 \text { mieszkańca } \\
\text { Waste generation intensities and recovery ratios } \\
\text { By sector, per unit of GDP or VA, per capita } \\
\text { Putrient flows and balances (N,P) } \\
\text { Bilans składników odżywczych w rolnictwie (azot, fosfor) } \\
\text { na powierzchnię gruntów rolnych i zmiany w produkcji rolnej } \\
\text { Nutrient balances in agriculture (N, P) per agricultural land area and change } \\
\text { in agricultural output }\end{array}$ \\
\hline $\begin{array}{l}\text { Wieloczynnikowa } \\
\text { efektywność } \\
\text { Multi-factor pro- } \\
\text { ductivity }\end{array}$ & $\begin{array}{l}\text { Wieloczynnikowa efektywność odzwierciedlająca usługi środowiskowe (miara } \\
\text { kompleksowa; oryginalne jednostki w kategoriach pieniężnych) } \\
\text { Multi-factor productivity reflecting environmental services } \\
\text { (comprehensive measure; original units in monetary terms) }\end{array}$ \\
\hline
\end{tabular}

Źródło: [Monitoring Progress..., 2013, s. 20]. 
TABELA 6.

Wskaźniki aktywów naturalnych

\begin{tabular}{|c|c|}
\hline $\begin{array}{l}\text { Grupa / zagadnienia } \\
\text { Group / theme }\end{array}$ & $\begin{array}{l}\text { Proponowane wskaźniki } \\
\text { Proposed indicators }\end{array}$ \\
\hline \multicolumn{2}{|r|}{$\begin{array}{l}\text { Aktywa naturalne } \\
\text { Natural asset base }\end{array}$} \\
\hline $\begin{array}{c}\text { Zasoby naturalne } \\
\text { Natural resource stocks }\end{array}$ & $\begin{array}{ll}\text { 1. Wskaźnik zasobów naturalnych; miara kompleksowa } \\
\text { Index of natural resources; comprehensive measure }\end{array}$ \\
\hline $\begin{array}{l}\text { Zasoby odnawialne } \\
\text { Renewable stocks }\end{array}$ & $\begin{array}{l}\text { 2. Zasoby wody słodkiej } \\
\text { Freshwater resources } \\
\text { Dostępne odnawialne zasoby naturalne (wody podziemne, powierzchniowe) } \\
\text { i powiązane wskaźniki poboru (krajowe, terytorialne) } \\
\text { Available renewable natural resources (groundwater, surface water) and related } \\
\text { abstraction rates (national, territorial) } \\
\text { 3. Zasoby leśne } \\
\text { Forest resources } \\
\text { Powierzchnia i zasoby leśne; zmiany zasobów w czasie } \\
\text { Area and volume of forests; stock changes over time } \\
\text { Zasoby rybne } \\
\text { Fish resources } \\
\text { Odsetek zasobów rybnych w bezpiecznych granicach biologicznych } \\
\text { (globalnie) } \\
\text { Proportion of fish stocks within safe biological limits (global) }\end{array}$ \\
\hline $\begin{array}{l}\text { Zasoby nieodnawialne } \\
\text { Non-renewable stocks }\end{array}$ & $\begin{array}{l}\text { 5. Zasoby minerałów } \\
\text { Mineral resources } \\
\text { Dostępne (globalne) zasoby lub rezerwy wybranych minerałów: minerały } \\
\text { metaliczne, przemysłowe, paliwa kopalne, kluczowe surowce i powiązane } \\
\text { wskaźniki wydobycia } \\
\text { Available (global) stocks or reserves of selected minerals: metallic minerals, } \\
\text { industrial minerals, fossil fuels, critical raw materials; and related extraction rates }\end{array}$ \\
\hline $\begin{array}{l}\text { Bioróżnorodność i ekosystemy } \\
\text { Biodiversity and ecosystems }\end{array}$ & $\begin{array}{l}\text { 6. Zasoby ziemi } \\
\text { Land resources } \\
\text { Rodzaje pokrycia terenu, przekształcenia i zmiany pokrycia } \\
\text { Land cover types, conversions and cover changes } \\
\text { Stan i zmiany od stanu naturalnego do stanu sztucznego i zmienionego } \\
\text { przez człowieka } \\
\text { State and changes from natural state to artificial or man-made state } \\
\text { - Użytkowanie gruntów: stan i zmiany } \\
\text { Land use: state and changes } \\
\text { Zasoby gleb } \\
\text { Soil resources } \\
\text { Stopień straty warstwy uprawnej z gruntów rolnych i innych } \\
\text { Degree of top soil losses on agricultural land, other land } \\
\text { - Powierzchnia gruntów rolnych dotknięta erozją wodną według klas } \\
\quad \text { erozji } \\
\text { Agricultural land area affected by water erosion by class of erosion } \\
\text { Zasoby przyrody (w opracowaniu) } \\
\text { Wildlife resources (tbd) } \\
\text { - Trendy w populacjach ptaków krajobrazu rolnego, leśnych lub w } \\
\text { hodowli populacji ptaków } \\
\text { Trends in farmland or forest bird populations or in breeding bird populations } \\
\text { Stan zagrożenia gatunków: ssaki, ptaki, ryby, rośliny naczyniowe } \\
\text { w \% gatunków oszacowanych lub znanych } \\
\text { Species threat status: mammals, birds, fish, vascular plants in \% species as- } \\
\text { sessed or known } \\
\text { Trendy w liczebności gatunków } \\
\text { Trends in species abundance }\end{array}$ \\
\hline
\end{tabular}

Zródło: [Monitoring Progress..., 2013, s. 44]. 
TABELA 7.

Wskaźniki środowiskowej jakości życia

\begin{tabular}{|c|c|}
\hline $\begin{array}{c}\text { Grupa / zagadnienia } \\
\text { Group / theme }\end{array}$ & $\begin{array}{c}\text { Proponowane wskaźniki } \\
\text { Proposed indicators }\end{array}$ \\
\hline \multicolumn{2}{|r|}{$\begin{array}{l}\text { Środowiskowa jakość życia } \\
\text { Environmental quality of life }\end{array}$} \\
\hline $\begin{array}{l}\text { Zdrowie i zagrożenia śro- } \\
\text { dowiskowe } \\
\text { Environmental health and } \\
\text { risks }\end{array}$ & $\begin{array}{l}\text { 1. Problemy zdrowotne wywołane zanieczyszczeniem środowiska } \\
\text { i związane z tym koszty (np. utracone lata życia w zdrowiu na skutek } \\
\text { zanieczyszczenia) } \\
\text { Environmentally induced health problems \& related costs (e.g. years } \\
\text { of healthy life lost from degraded environmental conditions) } \\
\text { - Ekspozycja ludności na zanieczyszczenia powietrza } \\
\text { Population exposure to air pollution } \\
\text { 2. Ekspozycja na zagrożenia naturalne i przemysłowe oraz zwią- } \\
\text { zane z tym straty gospodarcze } \\
\text { Exposure to natural or industrial risks and related economic losses }\end{array}$ \\
\hline $\begin{array}{c}\text { Usługi środowiskowe } \\
\text { i udogodnienia } \\
\text { Environmental services and } \\
\text { amenities }\end{array}$ & $\begin{array}{l}\text { 3. Dostęp do oczyszczalni ścieków i wody pitnej } \\
\text { Access to sewage treatment and drinking water } \\
\text { 3.1. Ludność korzystająca z oczyszczania ścieków (przynajmniej } \\
\text { wtórnego, w relacji do optymalnego wskaźnika podłączenia) } \\
\text { Population connected to sewage treatment (at least secondary, in relation } \\
\text { to optimal connection rate) } \\
\text { 3.2. Ludność z dostępem do wody pitnej } \\
\text { Population with sustainable access to safe drinking water }\end{array}$ \\
\hline
\end{tabular}

Źródło: [Monitoring Progress..., 2013, s. 64].

Przeorientowanie tradycyjnego wzrostu na wzrost zielony wymaga zastosowania przez sektor rządowy i samorządowy wielu zróżnicowanych instrumentów w ramach różnorodnych reakcji politycznych (działań politycznych). Władza publiczna ma do dyspozycji wiele narzędzi politycznych, wymuszających określone zachowania jednostek zmierzające do zazielenienia gospodarki, takich jak: regulacje prawne, podatki czy dotacje. Mogą one wspierać działania na rzecz zwiększenia efektywności, np. wykorzystania komponentów środowiska przyrodniczego, a także dostarczać bodźców do rozwoju proekologicznych wzorców produkcji i konsumpcji. Monitorowanie tych instrumentów i działań oraz ich skutków powinno znaleźć się w centrum zainteresowania decydentów. Jednocześnie instrumenty te i działania tworzą nowe możliwości gospodarcze przez rozwój określonych rodzajów działalności generujących miejsca pracy i stymulujaccych wzrost gospodarczy. Wskaźniki reakcji politycznych i możliwości gospodarczych zamieszczono w tabeli 8.

Bazę dla rozwoju gospodarki stanowi społeczeństwo, z kolei, podstawą do funkcjonowania gospodarki i społeczeństwa jest środowisko. Stąd też, według OECD, aby móc przeanalizować w pełni stan zazielenienia gospodarki, należy przyjrzeć się także szerszemu otoczeniu, co następnie powoduje konieczność przedstawienia wskaźników obrazujących uwarunkowania społeczno-gospodarcze kraju. OECD zaproponowała śledzenie takich zagadnień, jak: poziom wzrostu gospodarczego, produktywność i handel, rynek pracy, edukacja, sytuacja dochodowa ludności, a wskaźniki je monitorujące zaprezentowano w tabeli 9. 
TABELA 8.

Wskaźniki reakcji politycznych i możliwości gospodarczych

\begin{tabular}{|c|c|}
\hline $\begin{array}{c}\text { Grupa/zagadnienia } \\
\text { Group/theme }\end{array}$ & $\begin{array}{c}\text { Proponowane wskaźniki } \\
\text { Proposed indicators }\end{array}$ \\
\hline \multicolumn{2}{|r|}{$\begin{array}{l}\text { Reakcje polityczne i możliwości gospodarcze } \\
\text { Economic opportunities and policy responses }\end{array}$} \\
\hline $\begin{array}{l}\text { Technologia i innowacje } \\
\text { Technology and innovation }\end{array}$ & 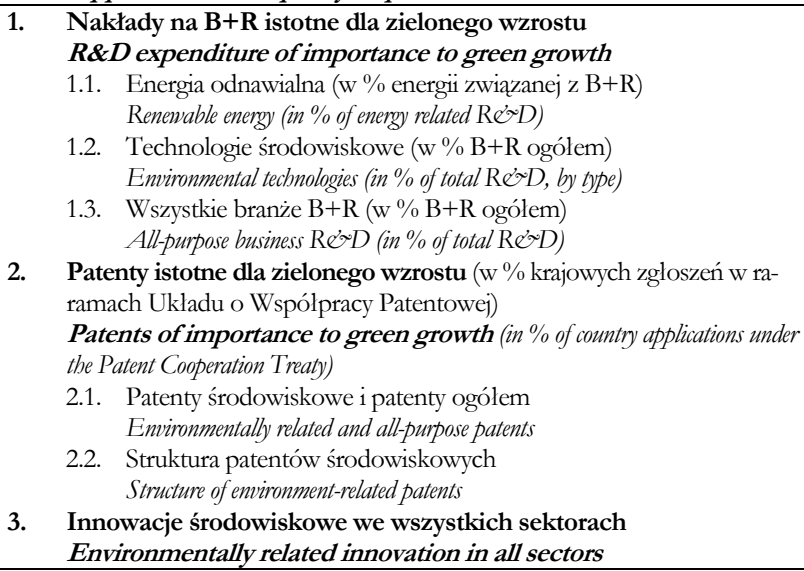 \\
\hline $\begin{array}{c}\text { Dobra i usługi środowiskowe } \\
\text { Environmental goods and ser- } \\
\text { vices }\end{array}$ & 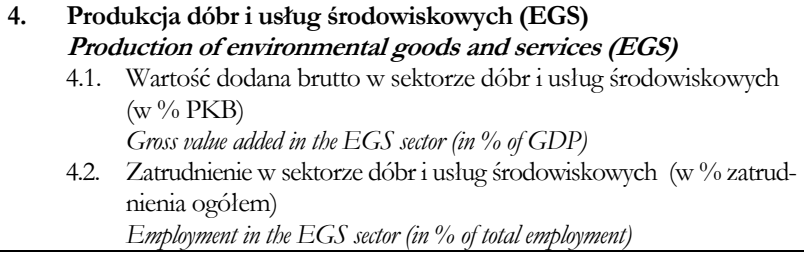 \\
\hline $\begin{array}{l}\text { Międzynarodowe przepływy fi- } \\
\text { nansowe } \\
\text { International financial flows }\end{array}$ & $\begin{array}{l}\text { 5. Międzynarodowe przepływy finansowe ważne dla zielonego wzro- } \\
\text { stu (w \% przepływów ogółem, w \% dochodu narodowego brutto) } \\
\text { International financial flows of importance to green growth (in \% of } \\
\text { total flows; in \% of global national income) } \\
\text { 5.1. Oficjalna Pomoc Rozwojowa } \\
\text { Official Development Assistance } \\
\text { 5.2. Finansowanie rynku węla } \\
\quad \text { Carbon market financing } \\
\text { 5.3. Bezpośrednie Inwestycje Zagraniczne } \\
\text { Foreign Direct Investment }\end{array}$ \\
\hline $\begin{array}{l}\text { Ceny i transfery } \\
\text { Prices and transfers }\end{array}$ & $\begin{array}{l}\text { 6. Podatki środowiskowe } \\
\text { Environmentally related taxation } \\
\text { 6.1. Poziom dochodów z tytułu podatków środowiskowych (w \% ogó- } \\
\text { łu dochodów podatkowych, w relacji do podatków z tytułu pracy) } \\
\text { Level of environmentally related tax revenues (in \% of total tax revenues, } \\
\text { in relation to labour related taxes) } \\
\text { 6.2. Struktura podatków środowiskowych (według rodzaju podstawy } \\
\text { opodatkowania) } \\
\quad \text { Structure of environmentally related taxes (by type of tax base) } \\
\text { 7. Ceny energii (udział podatków w cenie końcowej) } \\
\text { Energy pricing (share of taxes in end-use prices) } \\
\text { Ceny wody i zwrot kosztów (w opracowaniu) } \\
\text { Water pricing and cost recovery (to be developed) } \\
\text { Do uzupełnienia wskaźnikami z zakresu: } \\
\text { - subsydiów środowiskowych } \\
\text { - } \quad \text { wydatków środowiskowych: poziom i struktura } \\
\text { To be complemented with indicators on: }\end{array}$ \\
\hline
\end{tabular}




\begin{tabular}{|c|ll|}
\hline & & $\bullet \quad$\begin{tabular}{ll|} 
Environmentally related subsidies \\
Environmentaly related expenditure: level and structure
\end{tabular} \\
\hline $\begin{array}{c}\text { Rozporządzenia i przepisy oraz } \\
\text { metody zarządzania } \\
\text { Regulations and management } \\
\text { approaches }\end{array}$ & 9. & $\begin{array}{l}\text { Wskaźniki w opracowaniu } \\
\text { Indicators to be developed }\end{array}$ \\
\hline $\begin{array}{c}\text { Szkolenia i rozwój umiejętności } \\
\text { Training and skill development }\end{array}$ & 10. & $\begin{array}{l}\text { Wskaźniki w opracowaniu } \\
\text { Indicators to be developed }\end{array}$ \\
\hline
\end{tabular}

Źródło: [Monitoring Progress..., 2013, s. 72].

TABELA 9.

\section{Wskaźniki uwarunkowań społeczno-gospodarczych}

\begin{tabular}{|c|c|}
\hline $\begin{array}{l}\text { Grupa / zagadnienia } \\
\text { Group / theme }\end{array}$ & $\begin{array}{l}\text { Proponowane wskaźniki } \\
\text { Proposed indicators }\end{array}$ \\
\hline \multicolumn{2}{|c|}{$\begin{array}{l}\text { Uwarunkowania społeczno-gospodarcze } \\
\text { The socio-economic context and characteristics of growth }\end{array}$} \\
\hline $\begin{array}{l}\text { Wzrost gospodarczy, wy- } \\
\text { dajność i konkurencyjność } \\
\text { Economic growth, produc- } \\
\text { tivity and competitiveness }\end{array}$ & $\begin{array}{l}\text { W. Wzrost gospodarczy i struktura } \\
\text { Economic growth and structure } \\
\text { Wzrost PKB i struktura } \\
\text { GDP growth and structure } \\
\text { Rozporządzalny dochód netto } \\
\text { Net disposable income } \\
\text { W. Wydajność i handel } \\
\text { Productivity and trade } \\
\text { Wydajność pracy } \\
\text { Labour productivity } \\
\text { Wieloczynnikowa efektywność } \\
\text { Multi-factor productivity } \\
\text { Jednostkowe koszty pracy ważone handlem } \\
\text { Trade weighted unit labour costs } \\
\text { Względne znaczenie handlu: (export + import) / PKB } \\
\text { Relative importance of trade: (exports }+ \text { imports)/GDP } \\
\text { Inflacja i ceny towarów } \\
\text { Inflation and commodity prices } \\
\text { Indeks cen konsumpcyjnych } \\
\text { Consumer price index } \\
\text { Ceny żywności, ropy naftowej, minerałów, rud i metali } \\
\text { Prices of food; crude oil; minerals, ores and metals }\end{array}$ \\
\hline $\begin{array}{l}\text { Rynek pracy, edukacja } \\
\text { i dochód } \\
\text { Labour market, education } \\
\text { and income }\end{array}$ & $\begin{array}{l}\text { 4. Rynek pracy } \\
\text { Labour markets } \\
\text { Aktywność zawodowa } \\
\text { Labour force participation } \\
\text { Stopa bezrobocia } \\
\text { Unemployment rate } \\
\text { 5. Charakterystyka społeczno-demograficzna } \\
\text { Socio-demographic patterns } \\
\text { Wzrost liczby ludności, struktura i gęstość zaludnienia } \\
\text { Population growth, structure \&o density } \\
\text { Oczekiwana długość życia: trwanie życia w zdrowiu } \\
\text { Life expectancy: years of healthy life at birth } \\
\text { Nierówności dochodów: wskaźnik Giniego } \\
\text { Income inequality: GINI coefficient } \\
\text { Wykształcenie: Poziom i dostęp do edukacji } \\
\text { Educational attainment: level of and access to education }\end{array}$ \\
\hline
\end{tabular}

Źródło: [Monitoring Progress..., 2013, s. 6]. 
Zaprezentowany przez OECD zestaw wskaźników jest dość szeroki i stanowi otwarty katalog miar, które moga być wykorzystywane przez poszczególne kraje przystępujące do pomiaru zielonej gospodarki.

\section{Monitorowanie zielonej gospodarki na poziomie kraju}

Prace OECD w zakresie pomiaru zielonego wzrostu są częścią szerszego programu mierzenia dobrobytu i zrównoważonego rozwoju. Wskaźniki wraz ze strategią zielonego wzrostu OECD stały się podstawą do podjęcia inicjatyw zielonego wzrostu wśród części państw członkowskich OECD, m.in.: w Holandii, Czechach, Korei Południowej, Niemczech.

$\mathrm{Na}$ podstawie wytycznych, określonych przez OECD, każdy z tych krajów zaproponował monitorowanie przejścia gospodarki na zieloną i zaprezentował listę wskaźników pomiaru zielonego wzrostu, dostosowaną do specyfiki własnych państw oraz uwarunkowań miejscowych (tabela 10.).

TABELA 10.

Wybrane wskaźniki pomiaru zielonej gospodarki poszczególnych krajów

\begin{tabular}{|c|c|c|c|c|}
\hline Wskaźniki & Holandia & Czechy & $\begin{array}{l}\text { Korea Po- } \\
\text { łudniowa }\end{array}$ & Niemcy \\
\hline \multicolumn{5}{|c|}{ Efektywność wykorzystania walorów środowiska naturalnego i zasobów naturalnych } \\
\hline $\begin{array}{l}\text { Udział energii ze źródeł odnawialnych w końcowym zużyciu } \\
\text { energii brutto }\end{array}$ & $\mathrm{x}$ & $\mathrm{x}$ & $\mathrm{x}$ & $\mathrm{x}$ \\
\hline Produktywność zużycia wody & & $\mathrm{x}$ & & \\
\hline Zużycie wody na 1 mieszkańca & & & $\mathrm{x}$ & \\
\hline Intensywność zużycia wody & $\mathrm{x}$ & & & $\mathrm{x}$ \\
\hline \multicolumn{5}{|c|}{ Aktywa naturalne } \\
\hline Zapas drewna na pniu & $\mathrm{x}$ & $\mathrm{x}$ & $\mathrm{x}$ & $\mathrm{x}$ \\
\hline Rezerwy gazu ziemnego & $\mathrm{x}$ & & & \\
\hline Zasoby i pozyskanie węgla & & $\mathrm{x}$ & & \\
\hline Wkład akwakultury do produkcji ryb & & & $\mathrm{x}$ & \\
\hline Zużycie wody & & & & $\mathrm{x}$ \\
\hline \multicolumn{5}{|c|}{ Środowiskowa jakość życia } \\
\hline $\begin{array}{l}\text { Odsetek ludności podłączonej do wodociagu i kanalizacji } \\
\text { w \% ogółu }\end{array}$ & \multirow{5}{*}{$\mathrm{x}$} & \multirow[t]{5}{*}{$\mathrm{x}$} & \multirow{5}{*}{$\mathrm{x}$} & $\mathrm{x}$ \\
\hline Problemy zdrowotne, wywołane zanieczyszczeniem & & & & \\
\hline Średnia długość życia i lata życia w zdrowiu od urodzenia & & & & \\
\hline Powierzchnia terenów zieleni miejskiej na mieszkańca & & & & \\
\hline $\begin{array}{l}\text { Woda pitna, rozprowadzana konsumentom końcowym } \\
\text { dziennie, w litrach na mieszkańca }\end{array}$ & & & & $\mathrm{x}$ \\
\hline \multicolumn{5}{|c|}{ Reakcje polityczne i możliwości gospodarcze } \\
\hline Udział podatków środowiskowych w podatkach ogółem & $\mathrm{x}$ & $\mathrm{x}$ & $\mathrm{x}$ & $\mathrm{x}$ \\
\hline $\begin{array}{l}\text { Handel emisjami } \mathrm{CO}_{2} \text { - uprawnienia do emisji i rzeczywista } \\
\text { emisja } \mathrm{CO}_{2}\end{array}$ & $\mathrm{x}$ & & & $\mathrm{x}$ \\
\hline Wykształcenie ludności powyżej 15. roku życia & & $\mathrm{x}$ & & \\
\hline Udział Zielonej Oficjalnej Pomocy Rozwojowej & & & $\mathrm{x}$ & \\
\hline Cena wody pitnej i koszt na gospodarstwo domowe & & & & $\mathrm{x}$ \\
\hline
\end{tabular}

Źródło: [Green Growth in the Netherlands, 2011; Green Growth..., 2011; Korea's Green Growth..., 2012; Test of the OECD Set..., 2013]. 
Wraz z rozwojem inicjatyw budowania zielonej gospodarki na forum międzynarodowym, pojawia się konieczność wykształcenia statystycznych metod monitorowania i oceny stopnia jej zazielenienia w Polsce. Odpowiedzią na to zapotrzebowanie jest, przygotowywana przez Urząd Statystyczny w Białymstoku, koncepcja metodologii badania stanu zielonej gospodarki w Polsce (rysunek 5.), w której zostaną wykorzystane propozycje Organizacji Współpracy Gospodarczej i Rozwoju (OECD) w tym zakresie, jak również doświadczenia innych państw (Czech, Holandii, Korei Południowej, Niemiec). Stanowią one punkt wyjścia do zdefiniowania oraz ustalenia wstępnego zestawu wskaźników. Proponowane rozwiazzania w tym obszarze zostaną dostosowane do specyfiki naszego kraju.

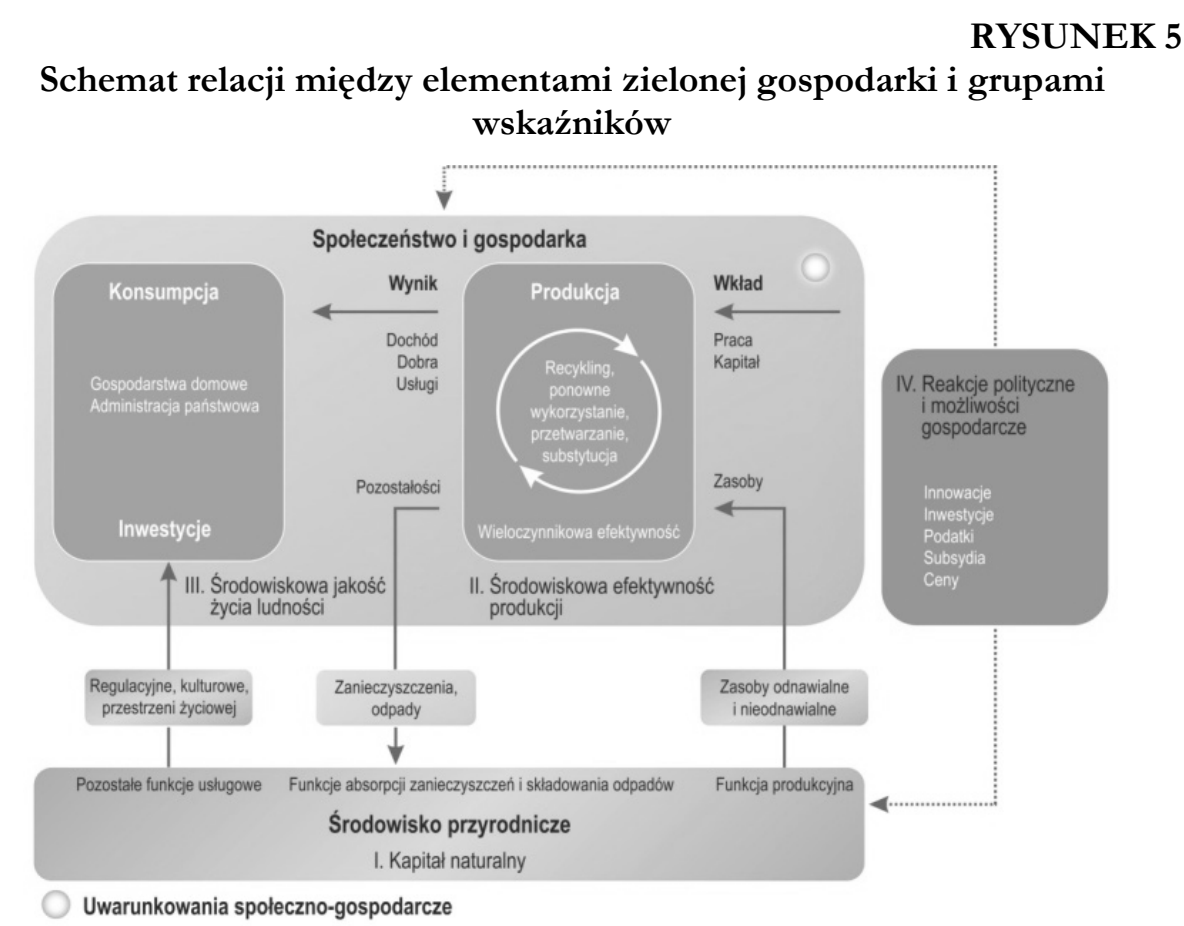

Źródło: opracowano w Podlaskim Ośrodku Badań Regionalnych Urzędu Statystycznego w Białymstoku.

Statystyka publiczna przy wsparciu innych instytucji krajowych (np. Głównego Inspektoratu Ochrony Środowiska) czy europejskich (np. Eurostat) dysponuje szerokim zakresem danych statystycznych, umożliwiającym dokonanie ogólnej oceny stopnia zazielenienia gospodarki. Jednak, z pewnościa, część propozycji wskaźników nie będzie mogła zostać wykorzystana do opisu stanu zielonej gospodarki w momencie zakończenia pracy metodologicznej, ze względu na brak danych do ich prezentacji, ale może stanowić podstawę propozycji zmiany zakresu lub sposobu zbierania danych, co pozwoliłoby na ich zastosowanie w przyszłości. 


\section{Podsumowanie}

UNEP i EEA, jako organizacje zaangażowane w kwestie środowiskowe, za punkt wyjścia do monitorowania zielonej gospodarki przyjmują środowisko, natomiast OECD, jako organizacja gospodarcza, zaczyna analizę od gospodarki. Jednakże współpracują one ze sobą w celu opracowania wspólnego zestawu kluczowych wskaźników pomiaru zielonej gospodarki. Mimo że nie wypracowano dotychczas jednolitego stanowiska co do sposobu monitorowania stopnia „zazielenienia” gospodarki, organizacje międzynarodowe, jak i poszczególne kraje, podejmujące ten temat, pozostaja zgodne, iż wzrost gospodarczy nie może dokonywać się kosztem stale rosnącej eksploatacji i degradacji kapitału naturalnego. W efekcie troska o odpowiedni stan środowiska wyraża się coraz częściej w uwzględnianiu aspektów ekologicznych w politykach, programach i strategiach rozwoju na każdym etapie ich tworzenia i wdrażania, zarówno na szczeblu: globalnym, europejskim, jak i krajowym. Przyświeca temu podstawowy cel, jakim jest zapewnienie dobrobytu społeczeństwa z jednoczesnym zachowaniem bezpieczeństwa poszczególnych obywateli. Jednak nie jest to możliwe do osiagnięcia przy nadmiernej presji na środowisko i jego zasoby. Proponowanym rozwiązaniem tego problemu jest zielona gospodarka, ukierunkowana na osiaganie rozwoju gospodarczego bez zbytniej eksploatacji środowiska. Zielona gospodarka to gospodarka aktywnie zaangażowana w propagowanie ekologicznych postaw całego społeczeństwa, jak i podmiotów gospodarczych, wspierająca wzorce i innowacje przyjazne środowisku przy jednoczesnym zachowaniu wysokiego poziomu rozwoju gospodarczego. Jej wdrażanie oraz analizowanie efektów wymaga wprowadzania systemu jej monitorowania.

\section{Literatura}

Environmental Indicator Report 2012. Ecosystem Resilience and Resource Efficiency in a Green Economy in Europe 2012, EEA, Kopenhaga.

Green Growth in the Czech Republic. Selected Indicators 2011, Czech Statistical Office Praga. Green Growth in the Netherlands 2011, Statistics Netherlands, Haga.

Korea Institute for International Economic Policy 2013 The Evolution of Green

Growth Policy: An Unwelcome Intrusion on Global Environmental Governance?, „Journal of East Asian Economic Integration", vol. 17, no. 2.

Korea's Green Growth based on OECD Green Growth Indicators 2012, Statistic Korea, Daejeon.

Measuring Progress towards an Inclusive Green Economy 2012, UNEP, Nairobi.

Monitoring Progress Towards Green Growth: OECD Indicators 2013 Report 2013, OECD.

Test of the OECD Set of Green Growth Indicators in Germany 2013, Federal Statistical Office of Germany, Wiesbaden.

Towards a Green Economy in Europe. EU Environmental Policy Targets and Objectives 2010-2050 2013, EEA, Kopenhaga.

Towards a Green Economy: Pathways to Sustainable Development and Poverty Eradication 2011, UNEP, Nairobi.

Towards Green Growth: Monitoring Progress. OECD Indicators 2011, OECD, Paryż. 